\title{
Stimulus Kredit Perbankan: Kebijakan Penanggulangan Risiko Kredit Akibat Coronavirus Disease 2019 (COVID-19) di Indonesia
}

\author{
Hari Sutra Disemadi ${ }^{1}$
}

${ }^{1}$ Fakultas Hukum, Universitas Internasional Batam, E-mail: hari@uib.ac.id

\begin{tabular}{l}
\hline Info Artikel \\
\hline Masuk:31 Maret2020 \\
Diterima:25 September 2021 \\
Terbit:30 September 2021 \\
Keywords: \\
Banking; Credit Risk; COVID-19; \\
Indonesia \\
\\
Kata kunci: \\
Perbankan; Risiko Kredit; COVID- \\
19; Indonesia \\
Corresponding Author: \\
Hari Sutra Disemadi, E-mail: \\
hari@uibac.id \\
DOI: \\
10.24843/IMHU.2021.v10.i03.p10 \\
\end{tabular}

\begin{abstract}
The spread of Coronavirus Disease 2019 or COVID-19 affects the economic stability of a country. Indonesia is one of the countries whose economic stability is disrupted due to the spread of COVID-19. The problem currently facing Indonesia is that the performance and capacity of debtors in carrying out their credit obligations has been disrupted by the spread of COVID19, which has the potential to disrupt banking performance in credit management. Therefore, the aim of this research is to find out and study the government's efforts in encouraging the banking intermediation function, maintaining financial system stability and supporting economicgrowth, a policy is needed as a legal strategy in overcoming the impact of the COVID-19 pandemic, particularly the impact on the performance and capacity of debtors in carry out its credit obligations. The research method used is a normative legal research method by utilizing legal materials. The results of this study indicate that the regulation of credit risk management policies in Indonesia has been regulated in existing laws and regulations such as the Law on Banking; Law concerning Sharia Banking; Bank Indonesia Regulations; and Financial Services Authority Regulations. The effort dhosen by the government in overcoming economic instability due to the spread of COVID-19 is the issuance of a policy to provide a national economic stimulus through the application of Financial Services Authority Regulation No. 11/POJK.03/2020. This policy is "countercyclical" due to the policies used in maintaining the stability of the economic cyde.
\end{abstract}

\begin{tabular}{l}
\hline Abstrak \\
\hline Penyebaran Coronavirus Disease 2019 atau COVID-19 \\
mempengaruhi kestabilan ekonomi suatu negara. Indonesia \\
merupakan salah satu negara yang kestabilan ekonominya \\
terganggu akibat penyebaran COVID-19. Permasalahan yang \\
dihadapi Indonesia saat ini adalah kinerja serta kapasitas debitur \\
dalam melaksanakan kewajiban kreditnya telah terganggu \\
dengan adanya penyebaran COVID-19, sehingga berpotensi \\
mengganggu kinerja perbankan dalam pengelolaan kredit. Maka \\
dari itu, tujuan penelitian ini adalah untuk mengetahui dan \\
mengkaji upaya pemerintah dalam mendorong fungsi \\
intermediasi perbankan, menjaga stabilitas sistem keuangan dan \\
mendukung pertumbuhan ekonomi diperlukan adanya \\
kebijakan sebagai strategi hukum dalam menanggulangi dampak
\end{tabular}




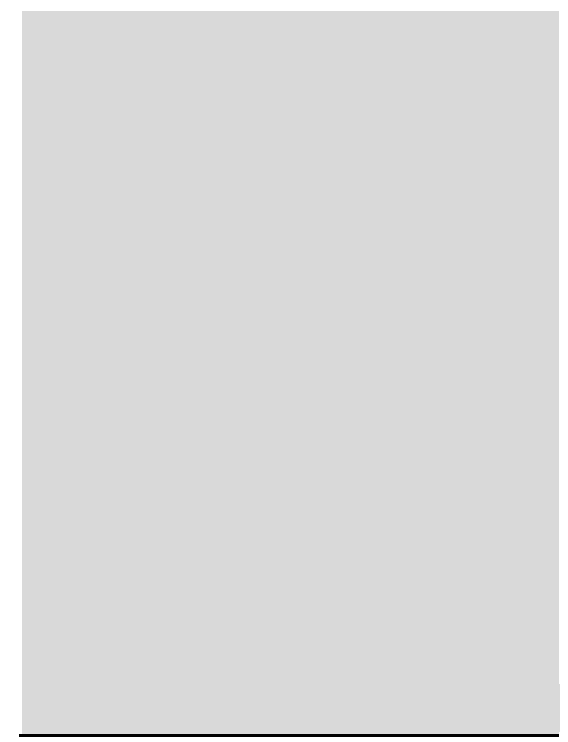

Pandemi COVID-19, khususnya dampak bagi kinerja serta kapasitas debitur dalam melaksanakan kewajiban kreditnya. Metode penelitian yang digunakan adalah metode penelitian hukum normatif dengan memanfaatkan bahan-bahan hukum. Hasil penelitian ini menunjukkan pengaturan kebijakan manajemen risiko kredit di Indonesia telah diatur dalam peraturan perundang-undangan yang ada seperti UndangUndang tentang Perbankan; Undang-Undang tentang Perbankan Syariah; Peraturan Bank Indonesia; dan Peraturan Otoritas Jasa Keuangan. Upaya yang dipilih oleh pemerintah dalam mengatasi ketidakstabilan perekonomian akibat penyebaran COVID-19 adalah diterbitkannya kebijakan pemberian stimulus perekonomian nasional melalui penerapan Peraturan Otoritas Jasa Keuangan No. 11/POJK.03/2020. Kebijakan ini bersifat "countercydical" dikarenakan kebijakan yang digunakan dalam menjaga kestabilan siklus perekonomian.

\section{Pendahuluan}

Dewasa ini, mobilisasi manusia serta barang sangat begitu cepat menyebabkan tidak ada negara yang kebal akan adanya epidemi. Munculnya berbagai macam penyakit menular seperti Flu Burung, SARS, Ebola dan penyakit menular lainnya mengingatkan kita sebagai manusia akan ancaman yang sangat berbahaya, yang tentu saja berpengaruh terhadap keamanan sosial serta kestabilan ekonomi suatu negara. Beberapa artikel jurnal internasional seperti yang ditulis oleh Tommaso Lupia et al pada tahun 20201; oleh Jiumen Sun et al pada tahun 20202; dan oleh Muhammad Adnan Shereen et al pada tahun $2020^{3}$, menyebutkan pada tahun 2019, dunia digemparkan dengan kemunculan virus baru. Virus ini pertama kali dilaporkan dari Wuhan-China dan dinamakan Coronavirus Disease 2019 atau yang lebih dikenal dengan sebutan COVID-19. Penyakit yang diakibatkan oleh COVID-I9 adalah infeksi yang sangat menular dan disebabkan oleh sindrom pernafasan akut coronavirus yang kemudian menyebar ke-beberapa negara lain di dunia. Penyebaran COVID-19 yang begitu cepat dikarenakan kemampuan penularannya adalah dari "manusia ke manusia". Kondisi kritis ini menyebabkan "World Health Organization (WHO) atau Organisasi Kesehatan Dunia" menetapkan Keadaan Darurat Kesehatan Publik Tingkat Internasional pada 31 Januari 2020. Mengingat fakta empiris bahwa belum ada obat efektif yang tersedia untuk menanggulangi COVID-19 maka, langkah-langkah pencegahan termasuk mengendalikan sumber penularan, deteksi dini pasien, memotong transmisi, dan melindungi populasi yang rentan adalah hal-hal yang terpenting.

\footnotetext{
1 Tommaso Lupia et al., “2019 Novel Coronavirus (2019-NCoV) Outbreak: A New Challenge,” Journal of Global Antimicrobial Resistance 21 (2020): 22-27, https://doi.org/https://dx.doi.org/10.1016/j.jgar.2020.02.021. h. 22

2 Jiumeng Sun et al., "COVID-19: Epidemiology, Evolution, and Cross-Disciplinary Perspectives," Trends in Molecular Medicine 26, no. 5 (2020): 483-95, https://doi.org/https://doi.org/10.1016/j.molmed.2020.02.008". h.1

3 Muhammad Adnan Shereen et al., "COVID-19 Infection: Origin, Transmission, and Characteristics of Human Coronaviruses," Journal of Advanced Research 24 (2020): 91, https://doi.org/https://doi.org/10.1016/j.jare.2020.03.005. h.1
} 
Berdasarkan Coronavirus Disease 2019 (COVID-19): Situation Report-51, pihak WHO menyampaikan "...that WHO has been assessing this outbreak around the clock and we are deeply concerned both by the alarming levels of spread and severity, and by the alarming levels of inaction. WHO therefore have made the assessment that COVID-19 can be characterized as a pandemic...".4 Secara sederhana WHO menyampaikan bahwa COVID-19 dikategorikan sebagai pandemi karena adanya tingkat penyebaran, keparahan dan kelambanan penanggulangan COVID-19.

11 Maret 2020, telah dikonfirmasi oleh WHO bahwa secara global terdapat 118.319 kasus diantaranya 4.620 kasus baru, 4.292 kematian diantaranya 280 kasus kematian baru. Di China sendiri terdapat 80.955 kasus yang telah dikonfirmasi diantaranya 31 kasus baru, 3.162 kematian diantaranya 22 kasus kematian baru. Di luar China terdapat 37.364 kasus yang diantaranya 4.589 kasus baru, kemudian terdapat 1.130 kasus kematian yang diantaranya 258 kasus kematian baru. ${ }^{5}$ Di Indonesia sendiri, pada tanggal 26 Maret 2020 berdasarkan situs resmi terkait informasi COVID-19 telah terkonfirmasi terdapat 893 kasus, diantaranya terdapat 780 pasien yang dirawat, terdapat 78 kasus meninggal dan terdapat 35 kasus yang sembuh dari COVID-19 ini. ${ }^{6}$

Seperti disebutkan sebelumnya bahwa adanya virus menular pada suatu negara akan memberikan pengaruh negatif bagi mobilitas manusia dalam berinteraksi sosial maupun melakukan kegiatan perekonomian. Dalam kegiatan perekonomian di Indonesia, dengan adanya perkembangan penyebaran COVID-19 berdampak secara langsung maupun tidak langsung terhadap stabilitas sistem keuangan dan kinerja perbankan pada suatu negara.

Penyaluran dana atau pinjaman (kredit) oleh bank kepada nasabah merupakan sumber pendapatan utama bank itu sendiri. Secara etimologis kredit berasal dari Bahasa Yunani yakni "credere" yang berarti kepercayaan, selain berasal dari Bahasa Yunani kredit berasal dari kata "credetum" yang berasal dari Bahasa Latin yang memiliki makna kepercayaan akan kebenaran. ${ }^{7}$ Hal ini berimplikasi bahwa setiap penyaluran kredit harus dilandasi kepercayaan. Kredit dapat diartikan sebagai penyediaan dana berdasarkan persetujuan maupun kesepakatan antara pihak bank dengan nasabah dengan dengan pemberian bunga. ${ }^{8}$

Penyaluran kredit oleh bank wajib berdasarkan tujuan kredit itu sendiri yaitu profitability dan safety. Tujuan kredit ini dimaksudkan untuk memperoleh keuntungan berupa bunga dari pokok pinjaman serta tujuan tujuan lain terhadap sebuah prestasi

\footnotetext{
4 World Health Organization, "Situation Report-51 Situation in Numbers Total and New Cases in Last 24 Hours," 2020, https:/ /www.who.int/docs/default-source/coronaviruse/situationreports/20200311-sitrep-51-covid-19.pdf?sfvrsn=1ba62e57_10.

5 World Health Organization, "WHO Director-General's Opening Remarks at the Media Briefing on COVID-19 - 11 March 2020," accessed March 24, 2020, https://www.who.int/director-general/speeches/ detail/who-director-general-s-openingremarks-at-the-media-briefing-on-covid-19---11-march-2020.

6 Situs Covid19 Indonesia," Virus Corona COVID-19," 2020, https://www.covid19.goid/.

7 Lukmanul Hakim and Travilta Oktaria, "Prinsip Kehati-Hatian Pada Lembaga Perbankan Dalam Pemberian Kredit," Keadilan Progresif 9, no. 2 (2018), https://doi.org/http://jurnal.ubl.ac.id/index.php/KP/article/view/1070. h.169

8 Ibid.
} 
dalam pengembalian pinjaman yang diberikan kepada nasabah. ${ }^{9}$ Roda bisnis suatu bank akan sangat bergantung pada pendapatan kredit untuk digunakan kembali sebagai modal bisnis berikutnya. ${ }^{10}$ Jelaslah pengelolaan kredit sangatlah penting, dimana apabila gagal dilakukan akan berdampak kerugian bagi bank dan bagi stakeholders lainnya seperti pengusaha yang akan menghadapi kesulitan dalam pendanaan usaha. Pengelolaan kredit ini sangat bergantung terhadap pro-aktifnya debitur (peminjam) dalam mengembalikan pinjamannya, sehingga pengelolaan kredit oleh bank akan sangat terganggu apabila debitur tidak melaksanakan kewajiban kreditnya (pembayaran serta pelunasan pinjaman). Permasalahan yang dihadapi Indonesia saat ini adalah kinerja serta kapasitas debitur dalam melaksanakan kewajiban kreditnya telah terganggu dengan adanya penyebaran COVID-19 sehingga berpotensi mengganggu kinerja perbankan dalam pengelolaan kredit khususnya. Oleh karena itu, untuk mendorong optimalisasi fungsi perbankan dalam intermediasi keuangan, serta untuk menjaga stabilitas sistem keuangan dan mendukung pertumbuhan ekonomi diperlukan adanya kebijakan sebagai strategi hukum dalam menanggulangi dampak penyebaran COVID-19 di Indonesia baik dampak langsung maupun dampak tidak langsung.

Penelitian sebelumnya yang terkait dengan penelitian saat ini adalah: oleh Gunarto Suhardi pada tahun 2006 yang berfokus pada risiko kredit dalam pemberian kredit perbankan11; Debora Damanik dan Paramita Prananingtyas pada tahun 2019 yang hanya berfokus pada prinsip kehati-hatian bank dalam menyalurkan kredit12; Ashofatul Lailiyah pada tahun 2014 yang berfokus pada analisa prinsip kehati-hatian (5C) pada pemberian kredit dalam meminimalisir resiko13; oleh Achmad Chosyali dan Tulus Sartono pada tahun 2019 yang berfokus pada peningkatan kualitas kredit dalam rangka mengatasi risiko kredit ${ }^{14}$; dan oleh Gabriela Ibrizul Wanura pada tahun 2020 yang berfokus pada prinsip kehati-hatian sebagai upaya pencegahan tindak pidana korupsi dalam pemberian KUR atau Kredit Usaha Rakyat pada masyarakat. ${ }^{15}$ Atas dasar beberapa kajian penelitian terdahulu, maka terdapat perbedaan fokus penelitian dengan penelitian kali ini. Meskipun memiliki kesamaan tema penelitian yang terkait penanganan risiko kredit, namun fokus pada penelitian kali ini adalah kebijakan

9 Achmad Chosyali and Tulus Sartono, "Optimalisasi Peningkatan Kualitas Kredit Dalam Rangka Mengatasi Kredit Bermasalah," Law Reform 15, no. 1 (2019): 98-112, https://doi.org/https://doi.org/10.14710/lr.v15i1.23357. h.111

10 Debora Damanik, "Prudential Banking Principles Dalam Pemberian Kredit Kepada Nasabah," NOTARIUS 12, no. 2 (2019): 718-30, https://doi.org/https://doi.org/10.14710/nts.v12i2.29011. h. 720

${ }^{11}$ Gunarto Suhardi, “Resiko Dalam Pemberian Kredit Perbankan," Jurnal Hukum Pro Justitia 24, no.

https://doi.org/http://journal.unpar.ac.id/index.php/projustitia/article/view/1181. h. 96

12 Damanik, "Prudential Banking Principles Dalam Pemberian Kredit Kepada Nasabah." h. 718

13 Ashofatul Lailiyah, "Urgensi Analisa 5c Pada Pemberian Kredit Perbankan Untuk Meminimalisir Resiko," Yuridika 29, no. 2 (2014), https://doi.org/10.20473/ydk.v29i2.368. h. 217

${ }^{14}$ Chosyali and Sartono, "Optimalisasi Peningkatan Kualitas Kredit Dalam Rangka Mengatasi Kredit Bermasalah." h. 98

15 Gabriela Ibrizul Wanura, "Prinsip Kehati-Hatian Bank Untuk Mencegah Indikasi Tindak Pidana Korupsi Dalam Pemberian Kredit Usaha Rakyat Pembibitan Hewan Ternak," JuristDiction 3, no. 1 (2020): 111-30, https:// doi.org/http://dx.doi.org/10.20473/jd.v3i1.17626. h. 111 
menjaga stabilitas risiko kredit perbankan sebagai upaya pemerintah dalam menanggulangi dampak penyebaran COVID-19 sehingga penelitian ini menjadi hal yang penting dan aktual untuk dilakukan pengkajian lebih lanjut. Maka dari itu, pada penelitian ini dapat dirumuskan permasalahan, yaitu mempertanyakan bagaimana kebijakan terhadap manajemen risiko kredit perbankan di Indonesia; dan mempertanyakan bagaimana kebijakan penanggulangan risiko kredit akibat COVID19 di Indonesia. Berkaca pada permasalahan yang di angkat, maka tujuan penelitian ini adalah untuk mengetahui kebijakan manajemen risiko kredit perbankan di Indonesia, dan untuk mengkaji upaya pemerintah dalam penanggulangan risiko kredit akibat Pandemi COVID-19.

\section{Metode Penelitian}

Penelitian ini menggunakan metode penelitian hukum normatif yang merupakan bagian dari tipology penelitian doctrinal. Pendekatan penelitian yang dipergunakan adalah pendekatan perundang-undangan dimana menggunakan data sekunder. Data sekunder dimaksud adalah bahan hukum primer maupun bahan hukum sekunder. Bahan hukum primer adalah bahan hukum yang sifatnya mengikat seperti "UndangUndang Nomor 10 Tahun 1998 tentang Perbankan (UU tentang Perbankan) dan Undang-Undang Nomor 21 Tahun 2008 tentang Perbankan Syariah (UU tentang Perbankan Syariah)" dan beberapa POJK atau Peraturan Otoritas Jasa Keuangan terkait. Sedangkan bahan hukum sekunder berupa buku-buku, artikel ilmiah, maupun artikel online yang terkait dengan kebijakan dalam penanggulangan risiko kredit akibat Coronavirus Disease 2019 (COVID-19).

\section{Hasil dan Pembahasan}

\subsection{Kebijakan Terhadap Manajemen Risiko Kredit Perbankan di Indonesia}

Eksistensi perbankan menjadi indikator dalam pertumbuhan dan perkembangan perekonomian.16 Hal ini dikarenakan perbankan dalam menjalankan usahanya tidak hanya bertujuan memperoleh keuntungan semata, melainkan juga mempunyai peran strategis terhadap pembangunan nasional berupa kesejahteraan rakyat. ${ }^{17}$ Spesifikasi fungsi perbankan yaitu sebagai agent of development, agent of trust, dan agent of services. 18 Secara sederhana diartikan sebagai entitas yang berfungsi dalam melancar kegiatan produksi, distribusi dan konsumsi; kemudian spesifikasi fungsi perbankan lainnya yaitu sebagai agent of trust yang berarti "trust" atau kepercayaan menjadi sandaran dasar segala kegiatan bank; selain agent of development dan agent of trust terdapat spesifikasi fungsi perbankan yang terakhir yaitu agent of service yang dimaknai

16 Lastuti Abubakar and Tri Handayani, "Telaah Yuridis Terhadap Implementasi Prinsip Kehati-Hatian Bank Dalam Aktivitas Perbankan Indonesia," DE LEGA LATA: Jurnal Ilmu Hukum 2, no. 1 (2017): 68-91, https://doi.org/https://doi.org/1030596/dll.v2i1.1157. h. 75

17 Fitriani Jamaluddin, "Mitigasi Resiko Kredit Perbankan," Al-Amwal: Journal of Islamic Economic Law 3, no. 1 (2018): 83-95, https://doi.org/https://doi.org/10.24256/alw.v3i1.201. h. 83

18 Abubakar and Handayani, "Telaah Yuridis Terhadap Implementasi Prinsip Kehati-Hatian Bank Dalam Aktivitas Perbankan Indonesia." h. 75 
bahwasanya perbankan memiliki fungsi memberikan pelayanan baik dalam bentuk barang maupun jasa (kegiatan menghimpun atau menyalurkan dana).19

Fungsi perbankan dalam menyalurkan kredit atau pembiayaan adalah kegiatan paling utama perbankan yang mengandung risiko dan sangat berdampak bagi "kesehatan" serta keberlangsungan usaha perbankan itu sendiri. ${ }^{20}$ Risiko-risiko dengan tingkat kompleksitas beragam pasti dan selalu melekat pada kegiatan usaha perbankan terutama pada kegiatan penyaluran kredit pada masyarakat. ${ }^{21}$ Risiko merupakan suatu potensi kerugian yang diakibatkan oleh terjadinya suatu peristiwa tertentu. Pada penelitian ini, risiko ini yang dimaksud dikenal dengan risiko kredit. Risiko kredit secara sederhana dimaknai sebagai "tidak lancarnya" nasabah (debitur) dalam mengembalikan pinjaman beserta bunganya atau lebih dikenal dengan "kredit macet". Tidak pro-aktifnya debitur ini akan menyebabkan kerugian pada bank karena di samping bank tidak memperoleh pendapatan berupa "bunga" dari pokok pinjaman, bank juga akan mengkompensasikan jumlah tagihan dengan modal.22

Di Indonesia sendiri dalam meminimalisir adanya risiko kredit pada perbankan dalam penyaluran kredit atau pembiayaan kepada nasabah, perbankan diwajibkan memenuhi ketentuan yang ada, salah satu contohnya adalah penerapan "prudential banking principle" atau yang lebih dikenal dengan prinsip kehati-hatian. Implementasi prudential banking principle merupakan upaya pencegahan adanya risiko dalam pemberian kredit sebelum dilakukan adanya keputusan pemberian kredit. ${ }^{23}$ Prudential banking principle dalam pemberian kredit perbankan di Indonesia dikenal dengan " the 5 $C^{\prime}$ 's analysis of credit" yang merupakan singkatan dari Character (karakter), Capacity (kapasitas), Capital (modal), Condition (status) dan Collateral (jaminan). ${ }^{24}$ Selain prinsip the $5 \mathrm{C}^{\prime}$ s analysis of credit dalam proses pemberian kredit, perbankan pun diwajibkan memperhatikan hal yang terkait dengan itikad baik dari nasabah atau debitur. Itikad baik ini juga dikenal dengan "willingness to pay". Selain kewajiban memperhatikan willingness to pay, perbankan juga diwajibkan memperhatikan "ability to pay" atau kemampuan dari debitur dalam melunasi kembali pinjaman beserta bunganya. ${ }^{25}$

Berdasarkan penelitian terdahulu oleh Debora Damanik \& Paramita Prananingtyas pada tahun 201926; dan oleh Lastuti Abubakar \& Tri Handayani pada tahun 201727,

${ }^{19}$ Hari Sutra Disemadi and Paramita Prananingtyas, "Perlindungan Hukum Terhadap Nasabah Perbankan Pengguna CRM (Cash Recycling Machine)," Jurnal Magister Hukum Udayana (Udayana Master Law Journal) 8, no. 3 (2019): 286-402, https://doi.org/: https://doi.org/10.24843/JMHU2019.v08.i03.p07.h. 391

20 Chosyali and Sartono, “Optimalisasi Peningkatan Kualitas Kredit Dalam Rangka Mengatasi Kredit Bermasalah." h. 99

${ }^{21}$ Muhammad Iqbal Fasa, "Manajemen Resiko Perbankan Syariah Di Indonesia," Li Falah: Jurnal Studi Ekonomi Dan Bisnis Islam 1, no. 2 (2017): 36-53, https://doi.org/http://dx.doi.org/10.31332/lifalah.v1i2.482. h.36

${ }^{22}$ Suhardi, "Resiko Dalam Pemberian Kredit Perbankan." h. 99

${ }^{23}$ Hari Sutra Disemadi, "Risk Management In The Provision Of People's Business Credit As Implementation Of Prudential Principles," Diponegoro Law Review 4, no. 2 (2019): 194-208, https://doi.org/https://doi.org/10.14710/dilrev.42.2019.194-208. h. 195

${ }^{24}$ Damanik, "Prudential Banking Principles Dalam Pemberian Kredit Kepada Nasabah." h. 725

${ }^{25}$ Lailiyah, "Urgensi Analisa 5c Pada Pemberian Kredit Perbankan Untuk Meminimalisir Resiko." h. 220

${ }^{26}$ Damanik, "Prudential Banking Principles Dalam Pemberian Kredit Kepa da Nasabah.” h. 722724 
menyebutkan pengaturan the $5 \mathrm{C}^{\prime} \mathrm{s}$ analysis of credit di Indonesia terdapat pada UU tentangPerbankan \& UU tentang Perbankan Syariah, dengan penjabaran sebagai berikut:

1) Pasal 8 UU tentang Perbankan serta Pasal 23 UU tentang Perbankan Syariah mengatur mengenai kewajiban perbankan untuk memiliki keyakinan berdasarkan the $5 C^{\prime} s$ analysis of credit sebelum memberikan kredit atau pembiayaan pada debitur. Pasal-pasal ini membedakan jaminan secara yuridis secara ekonomi. Secara yuridis yaitu keyakinan perbankan terkait yaitu itikad baik serta kesanggupan membayar, sedangkan keyakinan perbankan secara ekonomi terkait adanya jaminan atau agunan dari debitur;

2) Pasal 29 ayat (2) UU tentang Perbankan serta Pasal 35 UU tentang Perbankan Syariah yang mengatur kewajiban bank menerapkan prudential banking principle atau prinsip kehati-hatian. Pasal-pasal ini menekankan agar perbankan dapat memastikan terlaksananya proses pengambilan keputusan dalam pemberian kredit atau pembiayaan;

3) Pasal 29 ayat (3) UU tentang Perbankan serta Pasal 36 UU tentang Perbankan Syariah yang mengatur ketentuan kesehatan bank dan menjaga fungsinya sebagai agent of trust. Hal ini dikarenakan perbankan merupakan salah satu entitas keuangan yang melakukan kegiatan usaha dengan dana dari nasabah. Dana nasabah tersebut disimpan berdasarkan keyakinan serta kepercayaan nasabah itu sendiri terhadap perbankan, sehingga perbankan diwajibkan untuk menempuh cara-cara yang tidak merugikan kepentingan nasabah maupun perbankan itu sendiri;

4) Pasal 29 ayat (4) UU tentang Perbankan serta Pasal 39 UU tentang Perbankan Syariah yang mengatur ketentuan tentang informasi risiko kemungkinan kerugian sehubungan dengan adanya pemberian kredit atau pembiayaan;

Mengacu pada ruang lingkup prudential banking principle yang terdapat dalam UU tentang Perbankan dan UU tentang Perbankan Syariah di atas, dapat dikatakan kewajiban perbankan dalam menerapkan prudential banking principle atau prinsip kehati-hatian dilakukan sebelum pemberian kredit atau pembiayaan dilakukan atau diputuskan. ${ }^{28}$ Implementasi ketentuan mengenai prinsip kehati-hatian ini dimaksudkan untuk menghindari risiko kredit berupa "kredit macet" atau menghindari pembiayaan yang bermasalah. Selain itu implementasi prudential banking principle merupakan kewajiban perbankan dalam menjamin tindakan hukum dalam pemberian kredit atau pembiayaan yang dilakukan oleh perbankan mematuhi seluruh regulatory compliance atau peraturan perundang-undangan. ${ }^{29}$

Kondisi perbankan baik kondisi internal maupun kondisi eksternal mengalami perubahan serta perkembangan yang sangat pesat. Kondisi ini akan selalu diiringi dengan semakin kompleksnya risiko penyaluran kredit sehingga diperlukan adanya penerapan manajemen risiko atau risk management. ${ }^{30}$ Adapun kebijakan pengaturan

${ }^{27}$ Abubakar and Handayani, "Telaah Yuridis Terhadap Implementasi Prinsip Kehati-Hatian Bank Dalam Aktivitas Perbankan Indonesia." h. 77-78

${ }^{28}$ Damanik, "Prudential Banking Principles Dalam Pemberian Kredit Kepada Nasabah." h.724

${ }_{29}$ Abubakar and Handayani, "Telaah Yuridis Terhadap Implementasi Prinsip Kehati-Hatian Bank Dalam Aktivitas Perbankan Indonesia." h. 79

${ }^{30}$ Fasa, "Manajemen Resiko Perbankan Syariah Di Indonesia." h.36 
terkait implementasi risk management pada perbankan dalam pemberian kredit atau pembiayaan di Indonesia, adalah sebagai berikut:

Pertama, Peraturan Bank Indonesia (PBI) yang termuat dalam PBI No. 11/25/PBI/2009 tentang Penerapan Manajemen Risiko Bagi Bank Umum. Pokokpokok pengaturan PBI ini terkait kewajiban perbankan dalam mengimplementasikan risk management secara efektif; kewajiban perbankan menerapkan 4 (empat) risk management berupa risiko kredit, risiko pasar, risiko likuiditas serta risiko operasional31; kewajiban perbankan untuk mengklasifikasikan peringkat risiko menjadi 5 (lima) kategori yakni kategori 1 (Low), kategori 2 (Low to Moderate),kategori 3 (Moderate), kategori 4 (Moderate to High) serta kategori 5 (High) untuk perbankan konvensional sedangkan perbankan syariah dikategorikan menjadi 3 (tiga) peringkat, yaitu peringkat 1 (Low), peringkat 2 (Moderate), dan peringkat 3 (High); kemudian berdasarkan PBI ini bank diwajibkan mempunyai prosedur pengelolaan risiko termasuk risiko kredit. Prosedur pengelolaan risiko ini harus dituangkan secara tertulis.

Kedua, PBI No. 13/23/PBI/2011 tentang Penerapan Manajemen Risiko Bagi Bank Umum Syariah Dan Unit Usaha Syariah. Pengaturan risk management yang berlaku secara khusus ini diperlukan mengingat karakteristik kegiatan usaha Bank Umum Syariah serta Unit Usaha Syariah tidak sama sepenuhnya dengan risk management pada Bank Umum atau perbankan konvensional ${ }^{32}$, kemudian pengaturan ini adalah untuk memenuhi amanah Pasal 38 UU tentang Perbankan Syariah. Substansi pokok yang diatur dalam PBI ini adalah mengenai kewajiban implementasi manajemen risiko meliputi: pengawasan secara aktif oleh Direksi, Dewan Komisaris serta Dewan Pengawas Syariah (DPS), mengatur kecukupan kebijakan, prosedur, dan penetapan limit manajemen risiko; PBI ini mengatur kecukupan proses identifikasi, pengukuran, pemantauan serta pengendalian risiko, dan sistem informasi terkait risk management pada bank; PBI ini mengatur sistem pengendalian internal yang sifatnya menyeluruh; PBI ini juga mengatur kewajiban bank dalam implementasi risk management dengan disesuaikan dengan tujuan bank, kebijakan usaha bank, ukuran bank, dan kompleksitas usaha serta kemampuan bank itu sendiri.

Ketiga, Peraturan Otoritas Jasa Keuangan (POJK) yang termuat dalam POJK No. 18/POJK.03/2016 tentang Penerapan Manajemen Risiko Bagi Bank Umum. Pokokpokok pengaturan pada POJK ini adalah kewajiban bank dalam mengimplementasi risk management secara efektif; POJK ini selain mengatur risiko kredit, pada POJK ini terdapat juga risiko lainnya yaitu risiko likuiditas, risiko pasar, risiko hukum, risiko operasional, risiko strategi, risiko kepatuhan, dan risiko reputasi; POJK ini mengatur risk management terkait pengawasan secara aktif oleh Dewan Komisaris serta Direksi; pada POJK ini mengatur kebijakan prosedur risk management serta penetapan limit risiko; POJK ini juga mengatur terkait proses identifikasi, pengukuran, pemantauan, serta pengendalian risiko serta sistem informasi risk management; POJK ini juga mengatur terkait organisasi dan fungsi risk management; dan pengaturan lain yang

\footnotetext{
${ }^{31}$ Disemadi, "Risk Management In The Provision Of People's Business Credit As Implementation Of Prudential Principles." h. 201

32 Herlan Firmansyah and Mohamad Anton Athoillah, "Risk Analysis Of Islamic Banking Financing Business In Indonesia 2014-2018," Jurnal Ilmiah Al-Syir'ah 17, no. 2 (2019): 131-49, https://doi.org/http://dx.doi.org/10.30984/jis.v17i2.957.h. 136
} 
terdapat pada POJK ini adalah terkait pengelolaan risiko produk bank serta aktivitas baru yang ada pada bank.

Kempat, POJK No. 65/POJK.03/2016 tentang Penerapan Manajemen Risiko Bagi Bank Umum Syariah Dan Unit Usaha Syariah. Pokok-pokok pengaturan POJK ini adalah kewajiban bank menerapkan manajemen risiko atau risk management secara efektif teruntuk BUS atau Bank Umum Syariah serta UUS atau Unit Usaha Syariah; POJK ini juga mengatur terhadap wewenang dan tanggung jawab Direksi, Dewan Komisaris, dan DPS; POJK ini memuat pengaturan terkait kebijakan dan prosedur risk management serta penetapan limit risiko pada bank; POJK tahun 2016 ini juga mengatur proses identifikasi, pengukuran, pemantauan, dan pengendalian risiko serta sistem informasi risk management; dan POJK ini memuat pengaturan terkait sistem pengendalian internal bank serta memuat pengaturan terkait organisasi bank dan fungsi risk management bank.

Kelima, POJK No. 13/POJK.03/2015 tentang Penerapan Manajemen Risiko Bagi Bank Perkreditan Rakyat. Pokok-pokok pengaturan dalam POJK ini adalah kewajiban Bank Perkreditan Rakyat dalam mengimplementasikan risk management risiko kredit sampai dengan risiko stratejik; pengaturan POJK terkait risk management mencakup pengaturan pengawasan Direksi serta pengawasan Dewan Komisaris; POJK yang diterbitkan pada tahun 2015 ini juga mengatur kecukupan terkait kebijakan, prosedur risk management, dan penetapan limit risiko; POJK ini mengatur tentang kecukupan proses dan sistem risk management dalam proses identifikasi, pengukuran, pemantauan, serta pengendalian suatu risiko bank, serta sistem informasi risk management; dan kemudian POJK tahun 2015 ini juga mengatur tentang sistem pengendalian internal bank yang sifatnya menyeluruh.

Keenam, POJK No. 23/POJK.03/2018 tentang Penerapan Manajemen Risiko Bagi Bank Pembiayaan Rakyat Syariah. Substansi pengaturan POJK ini adalah Bank Pembiayaan Rakyat Syariah memiliki kewajiban dalam menerapkan risk management secara efektif yang melingkupi pengawasan secara aktif oleh Direksi terhadap bank, pengawasan aktif oleh Dewan Komisaris, dan pengawasan aktif oleh DPS; POJK yang diterbitkan pada tahun 2018 ini juga mengatur terkait kecukupan kebijakan risk management dan prosedur risk management serta penetapan limit risiko; POJK ini mengatur risk management terkait kecukupan proses identifikasi, pengukuran, pemantauan, dan pengendalian risiko kredit dan risiko bank lainnya; dalam POJK ini terdapat pengaturan terkait sistem informasi risk management serta sistem pengendalian internal bank yang bersifat menyeluruh.

Penggunaan frasa risiko kredit atau "credit risk", dikarenakan cakupan dari credit risk atau risiko kredit adalah termasuk di dalamnya pembiayaan yang mana dijalankan pada bank-bank yang menerapkan Hukum Islam atau Syariah, seperti BUS (Bank Umum Syariah), UUS (Unit Usaha Syariah), serta pada BPRS (Bank Pembiayaan Rakyat Syariah). Hal ini mengacu pada Guiding Principles of Risk Management For Institutions (Other Than Insurance Institutions) Offering Only Islamic Financial Services yang diterbitkan oleh The Islamic Financial Services Board (IFSB). 33

\footnotetext{
33Otoritas Jasa Keuangan, "Frequently Asked Question," 2018, https://www.ojk.goid/id/Default.aspx.
} 


\subsection{Kebijakan Penanggulangan Risiko Kredit Akibat COVID-19 Di Indonesia}

Di Indonesia, dengan adanya COVID-19 yang menyebar begitu cepat mengakibatkan melemahnya kinerja dan kapasitas debitur. Menurunnya kinerja dan kapasitas debitur ini secara langsung dapat meningkatkan credit risk atau risiko kredit yang pastinya akan berimbas terganggunya kinerja perbankan serta stabilitas keuangan di Indonesia. Fakta empiris ini mendorong Pemerintah Indonesia melalui Otoritas Jasa Keuangan atau OJK mengambil langkah hukum untuk memberikan pergerakan terhadap perbankan agar tidak mengganggu kinerja dan stabilitas keuangan.

Upaya atau langkah hukum yang dipilih oleh pemerintah ini adalah kebijakan pemberian stimulus perekonomian nasional untuk meredam dampak COVID-19. Kebijakan tersebut mulai diberlakukan pada tanggal 13 Maret 2020 sampai 31 Maret 2021 melalui penerapan POJK No. 11/POJK.03/2020 tentang Stimulus Perekonomian Nasional Sebagai Kebijakan Countercyclical Dampak Penyebaran Coronavirus Disease 2019 (POJK No. 11/POJK.03/2020). Dikatakan sebagai kebijakan "countercyclical" dikarenakan POJK No. 11/POJK.03/2020 ini merupakan kebijakan yang digunakan dalam menjaga kestabilan siklus perekonomian. Kebijakan yang bersifat countercyclical merupakan karakter kebijakan fiskal dan kebijakan moneter. ${ }^{34}$ Kebijakan countercyclical dimaknai sebagai kebijakan proaktif dari pemerintah untuk mengatasi pergerakan siklus ekonomi yang bersifat ekstrim. Pergerakan siklus perekonomian yang bersifat ekstrim ini bisa berupa booming (perkembangan yang sangat pesat). ${ }^{35}$ Kondisi booming, pemerintah dapat secara langsung mengurangi aktivitas ekonomi agar aktivitas ekonomi tersebut tidak masuk atau "terjerumus" pada overheating (pemanasan kegiatan perekonomian). Adanya aktivitas ekonomi yang overheating akan mampu dan dapat berdampak pada naiknya laju inflasi, sehingga perlu adanya kebijakan untuk mengerem atau menghentikannya berupa kebijakan moneter, kebijakan fiskal ataupun kombinasi dari kebijakan moneter dengan kebijakan fiskal. Pola penerapan kebijakankebijakan ini dikenal dengan countercyclical monetary policy. ${ }^{36}$

Alasan penerbitan kebijakan yang sifatnya countercyclical secara sepintas dirasa cukup sesuai untuk diimplementasikan agar siklus perekonomian Indonesia mampu terhindar pergerakan siklus perekonomian yang esktrim (booming) seperti adanya gejolak struktural (shocks) atau fluktuasi kegiatan ekonomi. 37 Hadirnya POJK No. 11/POJK.03/2020 di Indonesia adalah dikarenakan adanya fluktuasi kegiatan ekonomi, fluktuasi kegiatan ekonomi ini hadir dikarenakan perkembangan serta penyebaran COVID-19 di Indonesia. Penyebaran COVID-19 sangat berdampak baik secara langsung ataupun tidak langsung terhadap kinerja dan kapasitas debitur. Dampak ini turut berpotensi menghadirkan gangguan terhadap kinerja perbankan di Indonesia dan mengganggu stabilitas sistem keuangan, yang pada akhirnya mempengaruhi pertumbuhan ekonomi Indonesia. Maka dari itu, agar dapat mendorong optimalisasi fungsi intermediasi perbankan, mendukung adanya

${ }^{34}$ Muhammad Sahirul Alim and Akhmad Syakir KURNIA, "Karakter Kebijakan (Procyclical Vs Countercyclical) Dan Stabilitas Makroekonomi: Studi Empiris Asian Emerging Economies Periode2000-2012" (Fakultas Ekonomika dan Bisnis, 2014).

35Abdurahman, "Kebijakan Fiskal Countercyclical," 2009, https://rahman212.wordpress.com/2009/08/11/kebijakan-fiskal-countercyclical/.

36 P Warijoyo and Solikin, Kebijakan Moneter Di Indonesia: Seri Kebanksentralan No. 6 (Jakarta:

Pusat Pendidikan dan Studi Kebanksentralan, 2003). h. 4

37 Ibid. h. 5 
pertumbuhan ekonomi, serta menjaga stabilitas sistem keuangan negara diperlukan kebijakan stimulus perekonomian akibat dampak penyebaran COVID-19.

Berdasarkan penjelasan Pasal 2 ayat 1 POJK No. 11/POJK.03/2020, yang dimaksud dengan debitur (nasabah) yang terkena dampak adanya penyebaran COVID-19 adalah debitur yang mengalami kesulitan untuk memenuhi kewajiban pada bank karena debitur atau usaha debitur terdampak dari penyebaran COVID-19 baik yang terdampak secara langsung ataupun yang terdampak tidak langsung. Sektor-sektor perekonomian yang dimaksud pada POJK ini adalah sektor ekonomi terkait kepariwisataan, transportasi (darat, laut dan udara), perdagangan, perhotelan, pengolahan, pertambangan serta pertanian. Sebagai contohnya adalah sebagai berikut: 1). Debitur yang terkena dampak penutupan jalur transportasi dan pariwisata dari dan ke negara yang telah terdampak COVID-19 serta travel warning beberapa negara; 2). Debitur yang terkena dampak dari penurunan volume ekspor impor secara signifikan akibat keterkaitan rantai suplai dan perdagangan dengan negara yang telah terdampak COVID-19; 3). Debitur yang terkena dampak terhambatnya proyek pembangunan infrastruktur karena terhentinya pasokan bahan baku, tenaga kerja, dan mesin dari negara yang telah terdampak COVID-19.

Terbitnya POJK No. 11/POJK.03/2020 ini diharapkan agar perbankan dapat secara pro-aktif dalam mengidentifikasi debitur-debitur atau nasabahnya yang terdampak penyebaran COVID-19, yang kemudian perbankan diwajibkan segera mengimplementasikan atau menerapkan POJK No. 11/POJK.03/2020 dimaksud. Secara umum POJK No. 11/POJK.03/2020 ini diterbitkan untuk meminimalisir dampak penyebaran COVID-19 terhadap kinerja serta kapasitas debitur. Kinerja serta kapasitas debitur yang terkena dampak COVID-19 diperkirakan akan menurun sehingga pada akhirnya bisa meningkatkan credit risk atau risiko kredit. Risiko kredit inilah yang sangat berpotensi adanya gangguan terhadap kinerja perbankan di Indonesia. Maka dari itu, kebijakan ini berdasarkan ketentuan umum penjelasan POJK No. 11/POJK.03/2020 dapat diimplementasikan oleh perbankan dengan tetap memperhatikan prudential banking principle atau prinsip kehati-hatian pada perbankan yang disertai dengan pengelolaan risk management terkait mekanisme pemantauan risiko kredit.

Substansi pokok yang diatur dalam POJK No. 11/POJK.03/2020 ini adalah: Pertama, kebijakan ini berlaku bagi Bank Umum Konvensional atau BUK, Bank Umum Syariah atau BUS, Unit Usaha Syariah atau UUS, Bank Perkreditan Rakyat atau BPR, dan Bank Perkreditan Rakyat Syariah atau BPRS. Ketentuan ini terdapat pada Pasal 1 POJK No. 11/POJK.03/2020;

Kedua, atas adanya POJK ini perbankan dapat mengimplementasikan adanya kebijakan yang secara aktif mendukung stimulus pertumbuhan ekonomi untuk nasabah atau debitur baik secara langsung maupun tidak terdampak penyebaran COVID-19 termasuk debitur dari golongan UMKM atau Usaha Mikro, Kecil, dan Menengah). Dalam implementasi kebijakan ini mewajibkan perbankan untuk tetap memperhatikan prudential banking principle serta penerapan risk management bank secara aktif. Ketentuan ini terdapat pada Pasal 2 POJK No. 11/POJK.03/2020. Adapun penerapan risk management perbankan harus berdasarkan pedoman peraturan perundang-undangan yang ada, seperti: 1). POJK No. 18/POJK.03/2016 teruntuk BUK; 2). POJK No. 65/POJK.03/2016 teruntuk BUS dan UUS; 3). POJK No. 13/POJK.03/2015 teruntuk BPR; dan 4). POJK No. 23/POJK.03/2018 teruntuk BPRS. 
Ketiga, ketentuan Pasal 2 POJK No. 11/POJK.03/2020 juga mengklasifikasikan kriteria debitur mendapatkan perlakuan khusus untuk mendapatkan kebijakan stimulus kredit ini adalah nasabah atau debitur yang terdampak penyebaran COVID-19. Debitur ini adalah yang mengalami kesulitan untuk memenuhi kewajiban pada perbankan karena debitur atau usaha debitur terdampak dari penyebaran COVID-19 baik terdampak secara langsung ataupun terdampak secara tidak langsung. Seperti telah disebutkan sebelumnya contoh dari debitur yang terkena dampak penyebaran COVID-19 adalah:

1) Debitur yang terkena dampak penutupan jalur transportasi dan pariwisata dari dan ke negara yang telah terdampak COVID-19 serta travel warning beberapa negara;

2) Debitur yang terkena dampak dari penurunan volume ekspor impor secara signifikan akibat keterkaitan rantai suplai dan perdagangan dengan negara yang telah terdampak COVID-19; dan

3) Debitur yang terkena dampak terhambatnya proyek pembangunan infrastruktur karena terhentinya pasokan bahan baku, tenaga kerja, dan mesin dari negara yang telah terdampak COVID-19.

Keempat, kebijakan stimulus perekonomian pada POJK No. 11/POJK.03/2020 terdiri dari:

1) Kewajiban perbankan dalam melakukan penilaian kualitas kredit atau pembiayaan atau penyediaan dana lain yang hanya berdasarkan ketepatan pembayaran pokok dan/atau bunga untuk kredit atau pembiayaan atau penyediaan dana lain dengan plafon sampai dengan 10 miliar rupiah. Ketentuan ini diatur pada Pasal 3 dan 4 POJK No. 11/POJK.03/2020. Mengenai penilaian kualitas aset bagi BPR dan BPRS wajib berdasarkan ketentuan yang ada yaitu POJK mengenai kualitas aset produktif dan pembentukan penyisihan penghapusan aset produktif bank perkreditan rakyat bagi BPR, POJK mengenai kualitas aset produktif dan pembentukan penyisihan penghapusan aset produktif bank pembiayaan rakyat syariah bagi BPRS.

2) Kewajiban perbankan dalam meningkatkan kualitas kredit atau pembiayaan menjadi lancar setelah adanya proses restrukturisasi selama masa berlakunya POJK ini. Ketentuan merestrukturisasi dapat diterapkan perbankan tanpa melihat batasan plafon kredit atau pembiayaan ataupun jenis debitur (nasabah). Ketentuan ini diatur pada Pasal 5 dan Pasal 6 POJK No. 11/POJK.03/2020. Cara restrukturisasi kredit atau pembiayaan dilakukan sebagaimana diatur dalam POJK mengenai penilaian kualitas aset yang diantaranya dengan cara melakukan penurunan suku bunga oleh perbankan, perpanjangan jangka waktu kredit atau pembiayaan, pengurangan tunggakan pokok kredit atau pembiayaan, pengurangan tunggakan bunga kredit atau pembiayaan, penambahan fasilitas kredit atau pembiayaan dan/atau perbankan melakukan konversi kredit atau pembiayaan menjadi PMS atau Penyertaan Modal Sementara.

Kelima, perbankan dapat memberikan kredit atau pembiayaan ataupun penyediaan dana lain yang baru kepada nasabah (debitur) yang telah memperoleh perlakuan khusus sesuai kebijakan stimulus kredit ini dengan penetapan kualitas kredit atau pembiayaan atau penyediaan dana lain tersebut dilakukan secara terpisah dengan 
kualitas kredit atau pembiayaan atau penyediaan dana lain sebelumnya sesuai ketentuan yang terdapat pada Pasal 7 POJK No. 11/POJK.03/2020;

Keenam, perbankan wajib menyampaikan laporan berkala atas penerapan kebijakan stimulus kredit ini untuk monitoring Pengawas sesuai ketentuan Pasal 8 dan Pasal 9 POJK No. 11/POJK.03/2020. Berdasarkan penjelasan kebijakan stimulus kredit ini, penyampaian laporan kepada OJK ditujukan dengan alamat sebagai berikut:

1) Departemen Pengawasan Bank atau DPB terkait ataupun Kantor Regional OJK di Jakarta, bagi bank yang berkantor pusat ataupun kantor cabang dari bank yang berkedudukan di luar Indonesia yang berada di wilayah Provinsi Daerah Khusus Ibukota Jakarta serta Provinsi Banten; atau

2) Kantor Regional OJK atau Kantor OJK setempat, sesuai dengan wilayah tempat kedudukan dari kantor pusat bank.

Ketujuh, penerapan ketentuan kebijakan stimulus kredit ini hanya berlaku untuk debitur yang terkena dampak COVID-19 sejak diundangkan sampai dengan tanggal 31 Maret 2021, sesuai ketentuan Pasal 10 POJK No. 11/POJK.03/2020.

Adanya kebijakan POJK No. 11/POJK.03/2020 terkait stimulus kredit perbankan dapat dikatakan sebagai kebijakan dalam "mengakomodasi" fluktuasi siklus perekonomian akibat COVID-19. Kebijakan stimulus kredit perbankan yang bersifat countercyclical dimaksudkan untuk menanggulangi dampak penyebaran COVID-19 terhadap kinerja dan kapasitas debitur yang berpotensi menghadirkan "risiko kredit" dan dapat mengganggu stabilitas sistem keuangan serta kinerja perbankan di Indonesia.

\section{Kesimpulan}

Meminimalisir adanya risiko kredit pada perbankan dalam menyalurkan dana kepada debitur, perbankan diwajibkan memenuhi ketentuan yang ada, salah satunya penerapan prinsip kehati-hatian (prudential banking principle) sebelum memberikan kredit atau pembiayaan. Prudential banking principle sendiri diatur dalam UU tentang Perbankan dan UU tentang Perbankan Syariah. Prudential banking principle dikenal dengan "the 5C's analysis of credit" yang merupakan singkatan dari Character, Capacity, Capital, Condition dan Collateral. Di Indonesia, penyebaran COVID-19 mengakibatkan melemahnya kinerja dan kapasitas debitur. Menurunnya kinerja dan kapasitas debitur ini secara langsung dapat meningkatkan risiko kredit yang pastinya mengganggu kinerja perbankan dan stabilitas keuangan di Indonesia. Upaya pemerintah dalam menanggulangi risiko kredit akibat penyebaran COVID-19 adalah dengan mengeluarkan kebijakan pemberian stimulus perekonomian nasional untuk meredam dampak COVID-19. Kebijakan tersebut adalah POJK No. 11/POJK.03/2020. Kebijakan ini adalah kebijakan dalam "mengakomodasi" fluktuasi siklus perekonomian akibat COVID-19. Kebijakan stimulus kredit perbankan ini bersifat "countercyclical" yang secara sederhana sifat countercyclical diartikan sebagai penanggulangan dampak penyebaran COVID-19 terhadap kinerja dan kapasitas debitur yang berpotensi menghadirkan "risiko kredit" dan dapat mengganggu kinerja perbankan serta stabilitas sistem keuangan di Indonesia. 


\section{Daftar Pustaka}

Buku

Warijoyo, P, and Solikin. Kebijakan Moneter Di Indonesia: Seri Kebanksentralan No. 6. Jakarta: Pusat Pendidikan dan Studi Kebanksentralan, 2003.

\section{Jurnal}

Abubakar, Lastuti, and Tri Handayani. "Telaah Yuridis Terhadap Implementasi Prinsip Kehati-Hatian Bank Dalam Aktivitas Perbankan Indonesia." DE LEGA LATA: Jurnal Ilmu Hukum 2, no. 1 (2017): 68-91. https://doi.org/https://doi.org/10.30596/dll.v2i1.1157.

Alim, Muhammad Sahirul, and Akhmad Syakir KURNIA. "Karakter Kebijakan (Procyclical Vs Countercyclical) Dan Stabilitas Makroekonomi: Studi Empiris Asian Emerging Economies Periode 2000-2012" Fakultas Ekonomika dan Bisnis, 2014.

Chosyali, Achmad, and Tulus Sartono. "Optimalisasi Peningkatan Kualitas Kredit Dalam Rangka Mengatasi Kredit Bermasalah." Law Reform 15, no. 1 (2019): 98112. https://doi.org/https://doi.org/10.14710/lr.v15i1.23357.

Damanik, Debora. "Prudential Banking Principles Dalam Pemberian Kredit Kepada Nasabah." NOTARIUS 12, no. 2 (2019): 718-30. https://doi.org/https://doi.org/10.14710/nts.v12i2.29011.

Disemadi, Hari Sutra. "Risk Management In The Provision Of People's Business Credit As Implementation Of Prudential Principles." Diponegoro Law Review 4, no. 2 (2019): 194-208. https://doi.org/https://doi.org/10.14710/dilrev.4.2.2019.194208.

Disemadi, Hari Sutra, and Paramita Prananingtyas. "Perlindungan Hukum Terhadap Nasabah Perbankan Pengguna CRM (Cash Recycling Machine)." Jurnal Magister Hukum Udayana (Udayana Master Law Journal) 8, no. 3 (2019): 286-402. https://doi.org/: https://doi.org/10.24843/JMHU.2019.v08.i03.p07.

Fasa, Muhammad Iqbal. "Manajemen Resiko Perbankan Syariah Di Indonesia." Li Falah: Jurnal Studi Ekonomi Dan Bisnis Islam 1, no. 2 (2017): 36-53. https://doi.org/http://dx.doi.org/10.31332/lifalah.v1i2.482.

Firmansyah, Herlan, and Mohamad Anton Athoillah. "Risk Analysis Of Islamic Banking Financing Business In Indonesia 2014-2018." Jurnal Ilmiah Al-Syir'ah 17, no. 2 (2019): 131-49. https://doi.org/http://dx.doi.org/10.30984/jis.v17i2.957.

Hakim, Lukmanul, and Travilta Oktaria. "Prinsip Kehati-Hatian Pada Lembaga Perbankan Dalam Pemberian Kredit." Keadilan Progresif 9, no. 2 (2018). https://doi.org/http://jurnal.ubl.ac.id/index.php/KP/article/view/1070.

Jamaluddin, Fitriani. "Mitigasi Resiko Kredit Perbankan." Al-Amwal: Joumal of Islamic $\begin{array}{llllll}\text { Economic Law } & \text { 3, } & \text { 83-95. }\end{array}$ https://doi.org/https://doi.org/10.24256/alw.v3i1.201.

Lailiyah, Ashofatul. "Urgensi Analisa 5c Pada Pemberian Kredit Perbankan Untuk Meminimalisir Resiko." Yuridika 29, no. 2 (2014). https://doi.org/10.20473/ydk.v29i2.368.

Lupia, Tommaso, Silvia Scabini, Simone Mornese Pinna, Giovanni Di Perri, Francesco Giuseppe De Rosa, and Silvia Corcione. “2019 Novel Coronavirus (2019-NCoV) Outbreak: A New Challenge." Journal of Global Antimicrobial Resistance 21 (2020): 22-27. https://doi.org/https://dx.doi.org/10.1016/j.jgar.2020.02021.

Shereen, Muhammad Adnan, Suliman Khan, Abeer Kazmi, Nadia Bashir, and Rabeea Siddique. "COVID-19 Infection: Origin, Transmission, and Characteristics of 
Human Coronaviruses." Journal of Advanced Research 24 (2020): 91. https://doi.org/https://doi.org/10.1016/j.jare.2020.03.005.

Suhardi, Gunarto. "Resiko Dalam Pemberian Kredit Perbankan." Jurnal Hukum Pro Justitia 24, no. 12006 ). https://doi.org/http://journal.unpar.ac.id/index.php/projustitia/article/view $/ 1181$.

Sun, Jiumeng, Wan-Ting He, Lifang Wang, Alexander Lai, Xiang Ji, Xiaofeng Zhai, Gairu Li, Marc A Suchard, Jin Tian, and Jiyong Zhou. "COVID-19: Epidemiology, Evolution, and Cross-Disciplinary Perspectives." Trends in Molecular Medicine 26, no. 5 (2020): 483-95. https://doi.org/https://doi.org/10.1016/j.molmed.2020.02.008".

Wanura, Gabriela Ibrizul. "Prinsip Kehati-Hatian Bank Untuk Mencegah Indikasi Tindak Pidana Korupsi Dalam Pemberian Kredit Usaha Rakyat Pembibitan Hewan Ternak." Jurist-Diction 3, no. 1 (2020): 111-30. https://doi.org/http://dx.doi.org/10.20473/jd.v3i1.17626.

\section{Website}

$\begin{array}{llll}\text { Abdurahman. } & \text { "Kebijakan } & \text { Fiskal Countercyclical," }\end{array}$ https://rahman212.word press.com/2009/08/11/kebijakan-fiskalcountercyclical/.

Indonesia, Situs Covid19. "Virus Corona COVID-19," 2020. https: //www.covid19.go.id/.

Keuangan, Otoritas Jasa. "Frequently Asked Question," 2018. https://www.ojk.go.id/id/Default.aspx.

Organization, World Health. "Situation Report-51 Situation in Numbers Total and New Cases in Last 24 Hours," 2020. https://www.who.int/docs/defaultsource/coronaviruse/situation-reports/20200311-sitrep-51-covid19.pdf?sfvrsn=1ba62e57_10.

- - - ."WHO Director-General's Opening Remarks at the Media Briefing on COVID19 - 11 March 2020." Accessed March 24, 2020. https://www.who.int/directorgeneral/speeches/detail/who-director-general-s-opening-remarks-at-the-mediabriefing-on-covid-19---11-march-2020.

\section{Peraturan Perundangan}

Undang-Undang Nomor 10 Tahun 1998 tentang Perbankan

Undang-Undang Nomor 21 Tahun 2008 tentang Perbankan Syariah

PBI No. 11/25/PBI/2009 tentang Penerapan Manajemen Risiko Bagi Bank Umum

PBI No. 13/23/PBI/2011 tentang Penerapan Manajemen Risiko Bagi Bank Umum Syariah Dan Unit Usaha Syariah

POJK No. 18/POJK.03/2016 tentang Penerapan Manajemen Risiko Bagi Bank Umum

POJK No. 65/POJK.03/2016 tentang Penerapan Manajemen Risiko Bagi Bank Umum Syariah Dan Unit Usaha Syariah

POJK No. 13/POJK.03/2015 tentang Penerapan Manajemen Risiko Bagi Bank Perkreditan Rakyat

POJK No. 23/POJK.03/2018 tentang Penerapan Manajemen Risiko Bagi Bank Pembiayaan Rakyat Syariah

POJK No. 11/POJK.03/2020 tentang Stimulus Perekonomian Nasional Sebagai Kebijakan Countercyclical Dampak Penyebaran Coronavirus Disease 2019 